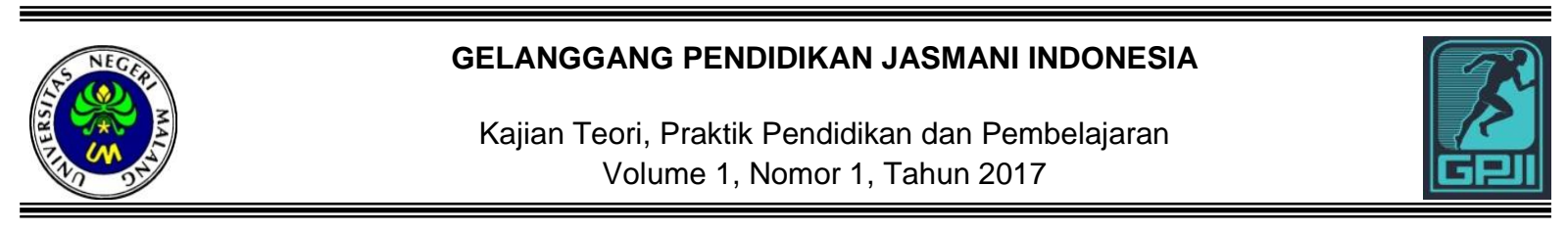

\title{
PENGEMBANGAN MODEL LATIHAN JUMP SHOOT UNTUK PESERTA EKSTRAKURIKULER BOLABASKET SMA NEGERI 1 KAUMAN KABUPATEN TULUNGAGUNG
}

\author{
Muhammad Faishol Harun \\ Oni Bagus Januarto \\ Usman Wahyudi \\ Fakultas IImu Keolahragaan Universitas Negeri Malang \\ Email: Faisholharun@gmail.com
}

\begin{abstract}
This study aimed to develop the exercise model of jump shoot for members of basketball extracurricular of SMA Negeri 1 Kauman, Tulungagung regency. This is expected that the members are able to understand and master jump shoot technique well and increase their skill. Data analysis techniques used in this research is qualitative analysis techniques (in the form of a sentence) and quantitative (in the form of a percentage). Qualitative data was used to analyze the data collected from the advice and review experts basketball game, a game of basketball coaching, media expert. While the analysis of quantitative data in the form of a percentage descriptive analysis techniques to present the results of the review expert basketball game, basketball game coaching experts, media experts, test a small group and large group trial.
\end{abstract}

Keywords: Developing, exercise model, jump shoot.

\begin{abstract}
Abstrak: Tujuan penelitian ini adalah untuk mengembangkan model latihan jump shoot untuk peserta ekstrakurikuler bolabasket SMA Negeri 1 Kauman Kabupaten Tulungagung. Dengan adanya pengembangan model latihan ini diharapkan peserta dapat memahami dan menguasai teknik jump shoot dengan baik dan benar serta dapat meningkatkan keterampilan para peserta ekstrakurikuler. Teknik analisis data yang digunakan dalam penelitian ini adalah teknik analisis kualitatif (berupa kalimat) dan kuantitatif (berupa persentase). Data kualitatif digunakan untuk menganalisis hasil pengumpulan data dari saran dan tinjauan para ahli permainan bolabasket, ahli kepelatihan permainan bolabasket, ahli media. Sedangkan analisis data kuantitatif berupa teknik analisis deskriptif persentase untuk menyajikan hasil tinjauan ahli permainan bolabasket, ahli kepelatihan permainan bolabasket, ahli media, uji coba kelompok kecil dan uji coba kelompok besar.
\end{abstract}

Kata Kunci: Pengembangan, model latihan, jump shoot.

Pendidikan jasmani merupakan bagian penting dari proses pendidikan yang mengajarkan tentang aktivitas jasmani. Karena dengan melakukan aktivitas jasmani semua peserta ekstrakurikuler dapat mengembangkan ketrampilan dan membiasakan hidup sehat, oleh karena itu pendidikan jasmani dan kesehatan motoriknya, kemampuan fisiknya, pengetahuan penalarannya dan terbiasa dengan pola hidup sehat. Sesuai dengan yang dikatakan Roesdiani (2012:23) yaitu "Pendidikan jasmani adalah proses pendidikan aktivitas jasmani yang direncanakan secara siste- matik yang bertujuan untuk mengembangakan dan meningkatkan individu secara orgaik, neuromuskuler, perseptual, kognitif, dan emosional, dalam kerangka pendidikan. Menurut pendapat dari Rohmawan (2014:69) berpendapat bahwa "Pendidikan jasmani merupakan suatu proses pendidikan yang memanfaatkan aktivitas jasmani yang direncanakan secara sistematis yang memiliki tujuan untuk mengembangkan aspek kesehatan, aspek kebugaran jasmani, keterampilan gerak, berfikir kritis, stabilitas emosional, tindakan moral dan penalaran." 
Muhammad Faishol Harun, Pengembangan Model Latihan Jump Shoot Untuk Peserta Ekstrakurikuler Bolabasket SMA Negeri 1 Kauman Kabupaten Tulungagung

Jadi dapat disimpulkan bahwa pendidikan jasmani adalah suatu pendidikan yang diberikan dengan memanfaatkan aktivitas jasmani yang direncanakan secara sistematik. Pendidikan jasmani merupakan suatu pendidikan yang mengembangkan aktivitas fisik, motorik dan pengetahuan untuk dapat menguasai kemampuan fisik.

Pada saat ini salah satu olahraga yang paling diminati oleh masyarakat adalah permainan bolabasket. Dalam perkembangannya dalam permainan bolabasket juga diberikan pada bidang pendidikan khususnya pada pelajaran pendidikan jasmani di sekolah. Hal ini sebenarnya juga mempengaruhi minat maupun rasa ingin tahu terhadap permainan bolabasket. Setiap sekolah biasanya mempunyai fasilitas yang diberikan kepada siswa dengan sarana dan prasarana yang ada antara lain lapangan bolabasket. Sekolah dapat mengadakan jam tambahan untuk siswa yang ingin menyalurkan bakat dan minatnya yaitu dengan mengikuti kegiatan ekstrakurikuler apa saja yang diinginkan. Menurut Lutan (1986:73) berpendapat bahwa "Ekstrakurikuler adalah segala macam aktivitas di sekolah atau lembaga pendidikan yang dilaksanakan di luar jam pelajaran wajib bagi setiap anak dan aktivitas itu termasuk dalam kurikulum yang telah tersusun bagi suatu tingkat kelas atau sekolah." Sedangkan menurut Usman dan Setiawati (1993:22) "Pengertian ekstrakurikuler merupakan kegiatan yang dilakukan di luar jam pelajaran (tatap muka) baik dilaksanakan di sekolah maupun di luar sekolah untuk lebih memperkaya dan memperluas pengetahuan dan kemampuan yang telah dimilikinya dari berbagai bidang studi".

Jadi dapat disimpulkan bahwa kegiatan ekstrakurikuler merupakan kegiatan yang dilakukan diluar jam sekolah sesuai dengan potensi, bakat, dan minat siswa dan sebagai fasilitas yang diberikan untuk mengembangkan minat, bakat, dan potensi siswa agar siswa tidak hanya berprestasi dalam bidang akademiknya saja melainkan juga berprestasi dalam bidang luar aka-demik. Kegiatan ekstrakurikuler juga sebagai sarana menyalurkan bakat atau mendorong perkembangan potensi siswa hingga mencapai kemampuan maksimal dan juga sebagai sarana untuk memperoleh prestasi contohnya jika seorang siswa ingin menya- lurkan bakat dan minatnya dalam olahraga bolabasket siswa bisa mengikuti kegiatan ekstrakurikuler bolabasket.

Permainan bolabasket saat ini berkembang pada sekolah-sekolah maupun Universitas yang ada di Indonesia dan banyak klub di Indonesia yang didirikan baik tim tersebut didirikan secara profesional maupun secara pemlua. Sehingga banyak orang yang sangat antusias dalam bermain permainan bolabasket. Muhajir (2007:11) juga berpendapat bahwa "Permainan bolabasket adalah suatu permainan yang dimainkan oleh 2 regu yang masing-masing regu terdiri atas 5 orang pemain. Jenis permainan ini bertujuan untuk mencari nilai atau angka sebanyak-banyaknya dengan cara memasukkan bola ke ring basket lawan dan mencegah lawan untuk mendapatkan nilai. Menurut Shaji dan Isya, (dalam Poomsalood dan Pakulanon, 2015:599) berpendapat bahwa "Basketball is one of the most popular team sports widely played and watched all over the world. Through time, basketball has improved to involve common techniques shooting, passing, and dribbling, including player positioning as well as offensive and defensive structures".

Dari pendapat Shaji dan Isya, (dalam Poomsalood dan Pakulanon, 2015:599) dapat diartikan "Permainan bolabasket adalah salah satu olahraga yang paling populer yang banyak dimainkan dan ditonton di seluruh dunia. Dari waktu ke waktu, permainan bolabasket telah meningkat dan memerlukan teknik umum seperti: teknik shooting, passing, dan dribbling, serta termasuk posisi pemain seperti offensive dan deffensive."

Jadi dapat disimpulkan bahwa permainan bolabasket adalah suatu per-mainan yang dimainkan oleh 2 tim yang masingmasing tim terdiri dari 5 orang pemain yang berada dalam lapangan dan memiliki tujuan untuk memasukkan bola ke dalam keranjang lawan sebanyak-banyaknya agar dapat menghasilkan angka bagi timnya. Apabila salah satu tim tersebut dapat memasukkan bola ke keranjang lawan lebih banyak dari tim lawanya dalam suatu pertandingan maka tim tersebut akan bisa memenangkan pertandingan. Permainan bolabasket adalah olahraga yang membutuhkan suatu penguasaan teknik yang harus dikuasai agar dapat bermain permainan bolabasket 
dengan baik. Dalam permainan bolabasket juga mempunyai aturan-aturan yang harus ditaati ketika bermain permainan bolabasket, apabila tim tersebut ingin dapat memenangkan pertandingan jika tim tersebut dapat bermain dengan baik, menguasai teknik dengan baik, mematuhi peraturan yang ada dan dapat mencetak angka sebanyak-banyaknya ke dalam ring basket lawan.

Permainan bolabasket juga diberikan pada bidang pendidikan khususnya pada pelajaran pendidikan jasmani di sekolah. Hal ini sebenarnya juga mempengaruhi minat, bakat maupun rasa ingin tahu terhadap permainan bolabasket.

Di setiap sekolah biasanya memfasilitasi siswanya dengan sarana dan prasarana yang ada antara lain lapangan bolabasket. Pada setiap sekolah mengadakan jam tambahan untuk siswa yang ingin menyalurkan bakat dan minatnya yaitu dengan mengikuti kegiatan ekstrakurikuler yang diinginkan. Kegiatan ekstrakurikuler bolabasket seorang pelatih harus melakukan pendekatan latihan yang tepat sehingga menghasilkan hasil latihan lebih optimal dan dalam kegiatan ekstrakurikuler bolabasket seorang pelatih harus bisa memberikan motivasi maupun progam latihan yang teratur kepada peserta ekstrakurikuler.

Dalam permainan bolabasket ada beberapa macam teknik dasar yang harus dikuasi diantaranya yaitu dribble (menggiring bola), passing (mengoper bola) dan shooting (memasukkan bola ke ring). Setiap teknik dasar tersebut memiliki fungsi yang berbeda satu sama lainya, mulai untuk bertahan dan untuk melakukan serangan. Pauweni (2012: 61) juga berpendapat bahwa "Permainan bolabasket memiliki teknik dasar permainan, yakni: (1) passing and catching (2) dribbling (3) shooting (4) pivot".

Menurut Berry, (dalam Pandey, dkk. 2012:2120) berpendapat bahwa "The game of Basketball involves ball handling, dribbling, passing, shooting and defense the ultimate aim of each team being to shoot the ball through the opponents' basket". Dari pendapat Berry, (dalam Pandey, dkk. 2012:2120) dapat diartikan "Dalam permainan bolabasket memerlukan teknik ball handling, dribbling, passing, shooting, dan defense. Tujuan akhir masing-masing tim yang menembak bola ke ring basket lawan".

Jadi dapat disimpulkan bahwa dalam permainan bolabasket seorang pemain harus menguasai teknik dasar dalam permainan bolabasket, teknik dasar dalam permainan bolabasket antara lain: dribble, (foodwork) gerakan kaki, (shooting) menembak, (passing) operan, rebound, bergerak dengan bola, bergerak tanpa bola, dan bertahan. Seorang pemain harus menguasai teknik dasar permainan bolabasket dengan baik. Untuk dapat menguasai teknik dasar permainan bolabasket dengan baik diperlukan latihan yang rutin dan kesungguhan dalam melakukan latihan tersebut. Penguasaan teknik dasar permainan bolabasket sangatlah berpengaruh dalam suatu tim, karena apabila suatu saat tim tersebut pemainnya tidak menguasai teknik dasar permainan bolabasket dengan baik maka tim tersebut sangatlah kesulitan untuk memenangkan pertandingan.

Teknik dasar untuk menyerang dalam permainan bolabasket salah satunya adalah shooting, di permainan bolabasket shooting sering digunakan untuk memasukkan bola ke dalam ring lawan dengan cara melempar bola, banyak cara untuk melakukan shooting atau tembakan dalam permainan bolabasket. Menurut Ahmadi (2007:18) shooting merupakan "usaha memasukkan ke keranjang diistilahkan dengan menembak, dapat dilakukan dengan satu tangan, dua tangan dan lay up". Shooting atau menembak adalah usaha untuk memasukkan bola ke dalam ring lawan untuk menghasilkan angka, semakin tinggi tingkat akurasi dan ketepatan shooting seorang pemain maka akan menyulitkan tim lawan. Wendry, dkk. (2012: 52) menyatakan "Menembak adalah hal yang terpenting dalam permainan basket dimana poin akan tercipta apabila mempunyai ke akuratan dalam menembak". Rodacki, (dalam Okazaki dan Rodacki, 2012:231) juga berpendapat bahwa "Basketball is a highly dynamic sport, in which players must perform shots from several distances from the basket'. Dari pendapat Rodacki, (dalam Okazaki dan Rodacki, 2012:231) dapat diartikan "Permainan bolabasket adalah suatu permainan yang sangat dinamis, di mana suatu pemain harus 
Muhammad Faishol Harun, Pengembangan Model Latihan Jump Shoot Untuk Peserta Ekstrakurikuler Bolabasket SMA Negeri 1 Kauman Kabupaten Tulungagung

melakukan tembakan dari beberapa jarak dari ring basket".

Jadi dapat disimpulkan bahwa shooting merupakan keterampilan yang sangat penting yang harus dikuasai oleh seorang pemain, shooting adalah usaha untuk memasukkan bola ke keranjang dengan tujuan mencetak angka sebanyakbanyaknya walaupun dalam keadaan dijaga oleh pemain lawan, teknik shooting dapat dilakukan dengan menggunakan satu tangan, dua tangan, dan lay up. Dari beberapa teknik shooting, teknik jump shoot merupakan teknik shooting yang sangat sering dilakukan oleh seorang pemain permainan bolabasket karena tembakan ini sulit dihalangi oleh pemain bertahan lawan karena tembakan ini dilakukan di titik tertinggi saat lompatan vertikal jump. Tembakan jump shoot bisa dilakukan dari jarak yang jauh seperti tembakan tiga angka dan dapat dilakukan dari berbagai arah. Menurut Liberman (1997:101) "Jump shoot adalah tembakan yang dilakukan baik dengan dua tangan ataupun satu tangan yang disertai loncatan, saat meloncat pada titik tertinggi bola dilepaskan menuju ring dengan cara mendorongkan bola menggunakan satu tangan terkuat dan satu tangan penyeimbang agar arah bola bisa melambung. Saichudin dan Januarto (1991:37) mengatakan bahwa "Apabila seorang pemain melakukan jump shoot dengan baik, ia merupakan ancaman yang berbahaya bagi lawan-lawannya untuk mencetak angka setiap saat, apabila ia menguasai bola. Untuk dapat menguasai teknik jump shoot diperlukan latihan yang teratur agar dapat menguasi teknik jump shoot dengan baik".

Jadi dapat disimpulkan bahwa jump shoot merupakan salah satu teknik shooting dan merupakan salah satu cara untuk memasukkan bola ke keranjang lawan yang dapat dilakukan dari jarak tertentu. Tembakan jump shoot merupakan salah satu tembakan yang sering dilakukan oleh pemain karena tembakan ini dapat dilakukan dengan dua tangan ataupun dengan satu tangan.

Observasi yang dilakukan pada ekstrakurikuler bolabasket SMA Negeri 1 Kauman Kabupaten Tulungagung terdapat beberapa temuan antara lain: pada saat latihan pelatih memberikan latihan shooting salah satunya yaitu melakukan jump shoot. Pada saat latihan pelatih jarang memberikan model latihan jump shoot. Ketika melakukan latihan jump shoot sebagian besar peserta masih kurang benar dalam melakukan teknik jump shoot akan tetapi ada beberapa peserta yang melakukannya dengan benar tetapi bola tidak masuk ke dalam ring dan melenceng. Ketika pelatih memberikan model latihan jump shoot banyak peserta kurang sungguh-sungguh dan terlihat bosan. Pelatih juga kurang memberikan variasi model latihan jump shoot sehingga para peserta yang latihan di ekstrakurikuler bolabasket tersebut terlihat jenuh dan bosan. Serta Model latihan jump shoot yang diberikan pelatih kurang menarik sehinga banyak peserta yang kurang antusias.

Dari analisis kebutuhan yang berupa kuesioner yang diberikan peneliti kepada pelatih ekstrakurikuler bolabasket SMA Negeri 1 Kauman Kabupaten Tulungagung didapatkan hasil: Pelatih ekstrakurikuler bolabasket SMA Negeri 1 Kauman Kabupaten Tulungagung mengatakan bahwa jump shoot merupakan teknik shooting yang tingkat keberhasilannya paling kurang, peserta kurang menguasai teknik jump shoot, peserta juga sangat sering mengalami kesulitan dalam melakukan teknik jump shoot, pelatih juga jarang memberikan model latihan jump shoot, pelatih juga setuju apabila peneliti mengembangkan model latihan jump shoot, pelatih juga setuju jika pengembangan model latihan jump shoot dikemas dalam bentuk buku saku.

Berdasarkan hasil kuisioner dari 38 peserta ekstrakurikuler bolabasket SMA Negeri 1 Kauman Kabupaten Tulungagung menyatakan bahwa (1) 32 peserta (84\%) menyatakan jump shoot merupakan teknik shooting yang paling sulit dilakukan, (2) 38 peserta (100\%) menyatakan pelatih jarang memberikan model latihan jump shoot, (3) 38 peserta (100\%) menyatakan model latihan jump shoot yang diberikan pelatih tidak menarik, (4) 38 peserta (100\%) menyatakan setuju jika peneliti mengembangkan model latihan jump shoot, (5) 34 peserta $(89 \%)$ memilih untuk pengembangan model latihan jump shoot dikemas dalam bentuk buku saku.

Menurut pendapat Sukmadinata (2005:164) "Pengembangan adalah me- 
ngembangkan suatu produk atau menyempurnakan produk yang telah ada dan produk tersebut dapat dipertanggungjawabkan. Sedangkan menurut Winarno (2011:76) penelitian pengembangan merupakan penelitian yang berupaya mengembangkan produk tertentu sesuai dengan kebutuhan masyarakat saat ini.

Jadi dapat ditarik kesimpulan bahwa penelitian dan pengembangan adalah upaya untuk mengembangkan sebuah produk yang belum ada ataupun memperbaiki produk yang sudah ada untuk memecahkan masalah yang ada atau untuk menerapkan temuan dan teori untuk memecakan masalah yang ada sesuai dengan kebutuhan.

Menurut Harsono (1988:101) menyatakan bahwa " Latihan adalah proses yang sistematis dari berlatih atau bekerja yang dilakukan secara berulang-ulang dengan kian hari kian menambah jumlah beban latihan atau pekerjaannya. Sedangkan menurut Budiwanto (2011:12) "Latihan adalah proses pembentukan kemampuan dan keterampilan atlet yang sistematis yang dilakukan secara berulang-ulang, semakin hari beban latihan semakin meningkat, dan dilaksanakan dalam kurun waktu yang panjang".

Jadi dapat disimpulkan bahwa latihan merupakan suatu kegiatan yang dilakukan supaya kemampuan dan keterampilan seorang pemain dapat meningkat. Latihan harus dilakukan dengan teratur dan sungguh-sungguh serta harus dilakukan secara berulang-ulang untuk mencapai tujuan yang ingin dicapainya.

Pelaksanaan latihan harus dengan perencanaan atau progam yang sesuai dengan kondisi seorang atlet. Menurut Bompa (dalam Hadisasmita dan Syarfudin,1996:130) prinsip-prinsip latihan sebagai berikut: "prinsip beban lebih (overload), prinsip perkembangan multilateral, prinsip intensitas latihan, prinsip berfikir positif, variasi dalam latihan, prinsip individualisasi, penetapan sasaran (goal setting), prinsip perbaikan kesalahan." Sedangkan Menurut Harsono (1988:102) menyatakan bahwa dengan berlatih secara sistematis dan melalui pengulanganpengulangan (repetitions) yang konstan, maka organisasi-organisasi mekanisme neurophysiologis akan menjadi bertambah baik, gerakan-gerakan yang semula sukar dilakukan lama-kelamaan akan merupakan gerakan-gerakan otomatis dan reflektif. Prinsip ini biasanya disebut dengan prinsip individual dan prinsip ini juga merupakan yang terpenting dalam training.

Jadi dapat disimpulkan bahwa latihan mempunyai beberapa prinsip antara lain: prinsip beban lebih (overload), prinsip perkembangan multilateral, prinsip intensitas latihan, prinsip berfikir positif, variasi dalam latihan, prinsip individualisasi. Latihan juga harus dengan perencanaan dan progam yang sesuai dengan kondisi seorang atlet dan tingkat kemampuan atlet tersebut dapat meningkatkan keterampilan dan prestasinya. Dengan latihan juga dapat mengembangkan karakter seorang atlet agar menjadi kuat.

Berdasarkan latar belakang masalah yang telah dipaparkan, maka peneliti ingin mencoba menemukan jalan keluar dengan mengembangkan model latihan jump shoot yang dikemas dalam bentuk buku saku. Buku saku mempunyai beberapa kelebihan antara lain: buku saku sangat praktis dan mudah dibawa kemana saja karena bisa disimpan dalam saku, buku saku juga dapat dipelajari di mana saja karena mudah untuk dibawa. Dengan pengembangan model latihan jump shoot yang dikemas dalam bentuk buku saku peserta ekstrakurikuler dapat menambah wawasan mereka tentang model-model latihan jump shoot pada permainan bolabasket, dan peserta ekstrakurikuler juga dapat mempelajari, membaca dan mempraktikkan model latihan jump shoot yang ada dalam buku saku sehingga peserta ekstrakurikuler tidak hanya berlatih pada saat latihan saja, tetapi dapat berlatih di luar jam latihan. Pengembangan model latihan jump shoot ini juga diharapkan dapat meningkatkan keterampilan dalam melakukan tenik jump shoot dan dapat mengembangkan kemampuan dalam melakukan teknik jump shoot untuk peserta ekstrakurikuler bolabasket serta membuat peserta ekstrakurikuler bolabasket lebih semangat lagi dan antusias dalam melakukan latihan.

Terdapat beberapa penelitian pengembangan terdahulu dalam permainan bolabasket yang relevan dengan pengembangan ini yaitu: 1) "Pengembangan VCD Latihan Jump Shoot Untuk Peserta 
Muhammad Faishol Harun, Pengembangan Model Latihan Jump Shoot Untuk Peserta Ekstrakurikuler Bolabasket SMA Negeri 1 Kauman Kabupaten Tulungagung

Ekstrakurikuler Bolabasket Putra Di SMP Negeri 1 Wlingi Kabupaten Blitar" yang ditulis oleh Tofan Budi Yanto tahun 2013, 2) "Pengembangan Model Latihan Teknik Jump Shoot Untuk Peserta Ekstrakurikuler Bolabasket Putra Di SMP Negeri 1 Trenggalek Melalui Video Pembelajaran Instruksional" yang ditulis oleh Bangkit Jerrytama tahun 2015. Berdasarkan analisis yang dijelaskan dan dengan pertimbangan dari penelitian sebelumnya, peneliti telah melakukan penelitian dengan judul "Pengembangan Model Latihan Jump Shoot Untuk Peserta Ekstrakurikuler Bolabasket SMA Negeri 1 Kauman Kabupaten Tulungagung".

Tujuan yang ingin dicapai dari penelitian ini adalah mengembangkan model latihan jump shoot pada ekstrakurikuler bolabasket SMA Negeri 1 Kauman Kabupaten Tulungagung agar lebih bervariasi sehingga peserta ekstrkurikuler dapat meningkatkan kemampuan jump shoot dalam permainan bolabasket dan juga demi untuk mencapai prestasi yang bagus.

\section{METODE}

Berdasarkan pada tujuan penelitian dan pengembangan ini yaitu mengembangkan produk berupa model latihan jump shoot untuk peserta ekstrakurikuler bolabasket SMA Negeri 1 Kauman Kabupaten Tulungagung, maka model penelitian dan pengembangan yang digunakan dalam penelitian ini berupa model konseptual (Mukhadis, 2013:98). Yang dimaksud dengan model konseptual yaitu model pengembangan yang berdasarkan operasionalisasi teori atau prinsip-prinsip yang telah tervalidasi ke dalam langkah-langkah atau prosedur yang mengarah suatu produk sebagai wujud pemecahan masalah (Mukhadis, 2013:98)

Model penelitian dan pengembangan merujuk pada langkah-langkah medote penelitian dan pengembangan Borg and Gall (1983:775) yang diterjemahkan ke dalam bahasa Indonesia sebagai berikut: (1) Melakukan penelitian dan pengumpulan informasi (kajian pustaka, pengamatan kelas, per-siapan laporan pokok persoalan), (2) Melakukan perencanaan (pendefinisian keterampilan, perumusan tujuan, penentuan urutan pengajaran, dan uji coba skala kecil),
(3) Mengembangkan bentuk produk awal (penyiapan materi pengajaran, penyusunan buku pegangan, dan perlengkapan evaluasi), (4) Melakukan uji coba lapangan permulaan (dilakukan pada 2-3 sekolah, penggunaan 6-12 subjek), (5) Melakukan revisi terhadap produk utama (sesuai dengan saran-saran dari hasil uji lapangan permulaan), (6) Melakukan uji lapangan utama (dengan 5-10 sekolah dengan 30-100 subjek), (7) Melakukan revisi produk (berdasarkan dari saran-saran dan hasil uji coba lapangan utama), (8) Uji lapangan meliputi 10-30 sekolah dengan 40-400 subjek, (9) Revisi produk akhir, (10) Membuat laporan mengenai produk pada jurnal, bekerja dengan penerbit yang dapat melakukan distribusi secara komersil.

Dari langkah-langkah yang sudah dikemukakan oleh Borg and Gall di atas, peneliti tidak menggunakan keseluruhan langkah-langkah tersebut, melainkan hanya mengambil 7 langkah saja, karena model pengembangan di atas tidak harus digunakan secara keseluruhan tetapi pengembang dapat memilih dan menen-tukan langkahlangkah yang paling tepat dengan menyesuaikan kondisi khusus dalam proses pengembangan. Peneliti dalam penelitian ini tidak sampai melakukan sampai langkah 8 yaitu uji lapangan meliputi 10-30 sekolah dengan 40-400 subjek karena dalam penelitian ini peneliti tidak melakukan uji lapangan untuk wilayah besar, peneliti juga tidak melakukan langkah 9 yaitu revisi produk akhir, karena peneliti tidak melakukan uji efektifitas produk, serta peneliti juga tidak melakukan langkah 10 yaitu membuat laporan mengenai produk pada jurnal, bekerja dengan penerbit yang dapat melakukan distribusi secara komersil, karena peneliti tidak melakukan persepsi dan diseminasi, karena ketiga langkah dari Borg and Gall tersebut mengarah pada penelitian eksperimen. Metode penelitian tersebut dimodifikasi dengan mengacu pada teori Ardhana (2002:9) yang menjelaskan bahwa pada setiap pengembangan tentu saja dapat memilih dan menentukan langkah-langkah yang paling tepat bagi dirinya berdasarkan kondisi khusus yang dihadapinya pada saat proses pengembangan.

Adapun langkah-langkah yang diambil yaitu sebagi berikut: (1) melakukan observasi dan penelitian untuk mengum- 
pulkan data awal dan analisis kebutuhan, (2) membuat produk awal berupa pengembangan model latihan jump shoot, (3) evaluasi 3 ahli yaitu 1 ahli permainan bolabasket, 1 ahli kepelatihan permainan bolabasket, 1 ahli media, (4) uji coba kelompok kecil yang menggunakan subjek 8 peserta ekstrakurikuler bolabasket SMA Negeri 1 Kauman Kabupaten Tulungagung, (5) Revisi produk awal sesuai dengan hasil uji coba kelompok kecil, (6) uji coba kelompok besar menggunakan subjek 30 peserta ekstrakurikuler bolabasket SMA Negeri 1 Kauman Kabupaten Tulungagung, (7) revisi produk akhir berdasarkan uji coba kelompok besar dan hasil akhir dari produk berupa pengembangan model latihan jump shoot untuk peserta ekstrakurikuler bolabasket SMA Negeri 1 Kauman Kabupaten Tulungagung.

Desain uji coba produk ini akan dilakukan melalui beberapa tahap yaitu: evaluasi dari beberapa ahli serta uji coba kelompok kecil dan uji coba kelompok besar serta revisi keseluruhan dari para ahli, uji coba kelompok kecil, uji coba kelompok besar. Tujuan dari keempat tahap tersebut adalah untuk memperoleh kesesuaian produk yang akan dikembangkan serta memperoleh keefektifan dari produk dalam penggunaannya. (1) Evaluasi Ahli. Pada evaluasi tahap ini bertujuan untuk mengetahui kesesuaian model yang hendak diproduksi dengan kebutuhan model latihan jump shoot. Evaluasi ahli dilakukan oleh: 1 ahli permainan bolabasket, 1 ahli kepelatihan permainan bolabasket,dan 1 ahli media dengan menggunakan angket. (2) Uji Coba Tahap I (kelompok kecil). Uji coba kelompok kecil dengan mengambil beberapa peserta ekstrakurikuler bolabasket SMA Negeri 1 Kauman Kabupaten Tulungagung sejumlah 8 peserta. Pengambilan data ini bertujuan untuk mengetahui reaksi dan tanggapan peserta ekstrakurikuler terhadap produk pengembangan yang telah dibuat. (3) Uji Coba Tahap II (kelompok besar). Pada tahap ini dilakukan uji lapangan (kelompok besar) yang dilakukan pada peserta ekstrakurikuler bolabasket SMA Negeri 1 Kauman Kabupaten Tulungagung dengan jumlah sebanyak 30 peserta. Pengambilan data ini bertujuan untuk mengetahui reaksi dan tanggapan peserta ekstrakurikuler terhadap produk pengembangan yang telah dibuat. (4) Revisi Produk. Hasil data kuisioner dari 1 ahli permainan bolabasket, 1 ahli kepelatihan permainan bolabasket, 1 ahli media, uji coba kelompok kecil, uji coba kelompok besar. Hasil data analisis dijadikan acuan untuk melakukan revisi dan perbaikan dari produk yang telah dibuat. Jenis data yang diperoleh pada penelitian ini adalah data kualitatif dan data kuantitatif, karena data yang diperoleh dinyatakan dengan kalimat dan angka. Data kualitatif diperoleh dari observasi, analisis kebutuhan dan tinjauan para ahli dan data kuantitatif tersebut diperoleh dari analisis kebutuhan, uji kelompok kecil, uji kelompok besar dan persentase angket.

Instrumen yang digunakan dalam pengembangan model latihan jump shoot untuk peserta ekstrakurikuler bolabasket SMA Negeri 1 Kauman Kabupaten Tulungagung ini menggunakan kuesioner yang diberikan kepada para ahli dan peserta ekstrakurikuler bolabasket.

Teknik analisis data yang digunakan dalam penelitian ini adalah teknik analisis kualitatif (berupa kalimat) dan kuantitatif (berupa persentase). Data kualitatif digunakan untuk menganalisis hasil pengumpulan data dari saran dan tinjauan para ahli permainan bolabasket, ahli kepelatihan permainan bolabasket, ahli media. Sedangkan analisis data kuantitatif berupa teknik analisis deskriptif persentase untuk menyajikan hasil tinjauan ahli permainan bolabasket, ahli kepelatihan permainan bolabasket, ahli media, uji coba kelompok kecil dan uji coba kelompok besar.

\section{HASIL}

Pada hasil pengembangan ini akan disajikan data analisis kebutuhan dari hasil penyebaran angket kepada pelatih dan 38 peserta ekstrakurikuler bolabasket SMA Negeri 1 Kauman Kabupaten Tulungagung. Selain itu juga akan disajikan data hasil evaluasi ahli permainan bolabasket, hasil evaluasi ahli kepelatihan permainan bolabasket, hasil evaluasi ahli media, hasil uji coba kelompok kecil, dan hasil uji coba kelompok besar. Uji coba kelompok kecil 
Muhammad Faishol Harun, Pengembangan Model Latihan Jump Shoot Untuk Peserta Ekstrakurikuler Bolabasket SMA Negeri 1 Kauman Kabupaten Tulungagung

mengunakan 8 peserta ekstrakurikuler bolabasket SMA Negeri 1 Kauman Kabupaten Tulungagung, sedangkan untuk uji coba kelompok besar menggunakan subjek penelitian sebanyak 30 peserta ekstrakurikuler bolabasket SMA Negeri 1 Kauman Kabupaten Tulungagung.

\section{Hasil Data Analisis Kebutuhan}

Analisis kebutuhan yang dilakukan peneliti yaitu dengan menyebarkan angket kepada pelatih dan peserta ekstrakurikuler bolabasket SMA Negeri 1 Kauman Kabupaten Tulungagung dengan hasil angket dari pelatih yaitu pelatih ekstra-kurikuler bolabasket SMA Negeri 1 Kauman Kabu-paten Tulungagung. Pelatih mengatakan bahwa teknik shooting yang tingkat keberhasilannya paling kurang adalah jump shoot, peserta kurang menguasai teknik jump shoot, peserta juga sangat sering mengalami kesulitan dalam melakukan teknik jump shoot, pelatih juga jarang memberikan model latihan jump shoot, pelatih setuju jika peneliti mengembangkan model latihan jump shoot, pelatih juga setuju jika pengembangan model latihan jump shoot dikemas dalam bentuk buku saku. Kemudian hasil angket dari peserta ekstrakurikuler bolabasket SMA Negeri 1 Kauman Kabupaten Tulungagung yaitu (1) sebanyak 32 peserta (84\%) menyatakan jump shoot merupakan teknik shooting yang paling sulit dilakukan, (2) sebanyak 38 peserta (100\%) menyatakan pelatih jarang memberikan model latihan jump shoot, (3) sebanyak 38 peserta (100\%) menyatakan model latihan jump shoot yang diberikan pelatih tidak menarik, (4) sebanyak 38 peserta (100\%) menyatakan setuju jika peneliti mengembangkan model latihan jump shoot, (5) sebanyak 34 peserta (89\%) memilih untuk pengembangan model latihan jump shoot dikemas dalam bentuk buku saku.

\section{Hasil Data Evaluasi Ahli}

Data hasil evaluasi ahli permainan bolabasket Oni Bagus Januarto, M. Kes. selaku Dosen jurusan Pendidikan Jasmani dan Kesehatan Fakultas IImu Keolahragaan Universitas Negeri Malang mengenai produk pengembangan berupa model latihan jump shoot untuk peserta ekstrakurikuler bolabasket SMA Negeri 1 Kauman Kabupaten Tulungagung, diperoleh hasil yaitu dari aspek kejelasan diperoleh persentase 78\% dengan kategori cukup valid, aspek kemenarikan diperoleh hasil $77,5 \%$ dan dari aspek kemanfaatan diperoleh persentase $77,5 \%$ dengan kategori cukup valid. Secara keseluruhan dari ketiga aspek tersebut diperoleh rata-rata keseluruhan persentase sebesar $78 \%$ dengan kategori kategori cukup baik.

Adapun saran-saran dari ahli permainan bolabasket terhadap hasil pengembangan model latihan jump shoot untuk peserta ekstrakurikuler bolabasket SMA Negeri 1 Kauman Kabupaten Tulungagung yaitu: (1) Font tulisan yang ada pada buku saku terlalu kecil. (2) Cover pada buku saku kurang menarik. (3) Header dan footer pada buku saku ditulis Nama, NIM, dan Jurusan.

Data hasil evaluasi ahli kepelatihan permainan bolabasket Ardhiansyah Rachmanu mengenai produk pengem-bangan berupa model latihan jump shoot untuk peserta ekstrakurikuler bolabasket SMA Negeri 1 Kauman Kabupaten Tulungagung, diperoleh hasil dari aspek kejelasan diperoleh persentase $78,8 \%$ dengan kategori cukup valid, dari aspek kemenarikan diperoleh hasil $80 \%$ dan dari aspek kemanfaatan diperoleh persentase $75 \%$ dengan kategori cukup valid. Secara keseluruhan dari ketiga aspek tersebut diperoleh rata-rata keseluruhan persentase sebesar $78 \%$ dengan kategori kategori cukup baik.

Adapun saran-saran dari ahli kepelatihan permainan bolabasket terhadap hasil pengembangan model latihan jump shoot untuk peserta ekstrakurikuler bolabasket SMA Negeri 1 Kauman Kabupaten Tulungagung yaitu: (1) Tulisan pada buku saku lebih sedikit diperbesar agar lebih mudah dipahami. (2) Gambar modelmodel latihan lebih diperbesar.

Data hasil evaluasi ahli media Eka Pramono Adi, S. I. P. M, Si. mengenai produk pengembangan model latihan jump shoot untuk peserta ekstrakurikuler bolabasket SMA Negeri 1 Kauman Kabupaten Tulungagung, diperoleh hasil yaitu dari aspek kejelasan diperoleh persentase $77 \%$ dengan kategori cukup valid, aspek kemenarikan diperoleh hasil $75 \%$, aspek kesesuaian $78,8 \%$ dan aspek pemahaman diperoleh persentase $75 \%$ dengan kategori cukup valid. Secara 
keseluruhan dari keempat aspek tersebut dapat diperoleh rata-rata keseluruhan persentase sebesar $78 \%$ dengan kategori kategori cukup baik.

Adapun saran-saran dari ahli media terhadap hasil pengembangan model latihan jump shoot untuk peserta ekstrakurikuler bolabasket SMA Negeri 1 Kauman Kabupaten Tulungagung yaitu meskipun berformat buku saku, usahakan keterbacaan tetap baik dan ukuran font sebaiknya 9-10 point.

\section{Hasil Data Uji Kelompok Kecil}

Uji coba kelompok kecil dilaksanakan pada tanggal 3, 5, dan 8 Maret 2016 pada pukul 15.00 sampai pukul 17.00 di lapangan bolabasket SMA Negeri 1 Kauman Kabupaten Tulungagung dengan menggunakan subjek 8 peserta ekstrakurikuler bolabasket SMA Negeri 1 Kauman Kabupaten Tulungagung, dan diperoleh hasil yaitu dari aspek kejelasan diperoleh persentase $81,5 \%$ dengan kategori cukup valid, dari aspek kemenarikan diperoleh persentase $84 \%$ dengan kategori cukup valid, aspek kemudahan dapat diperoleh persentase $80,6 \%$ dengan kategori cukup valid dan aspek kemanfaatan diperoleh persentase $86,5 \%$ dengan kategori sangat valid. Dari keempat aspek tersebut diperoleh rata-rata keseluruhan yaitu dengan persentase $83,2 \%$ dengan kategori cukup valid.

Adapun saran-saran dari uji coba kelompok kecil terhadap hasil pengembangan model latihan jump shoot untuk peserta ekstrakurikuler bolabasket SMA Negeri 1 Kauman Kabupaten Tulungagung sebagai berikut: (1) Ketera-ngan dari gambar model-model latihan jump shoot kurang jelas. (2) Model latihan jump shoot 1 sudah pernah diberikan pelatih. Oleh karena itu dari hasil uji coba kelompok kecil perlu adanya revisi agar dapat dipergunakan.

\section{Hasil Data Uji Coba Kelompok Besar}

Uji coba kelompok besar dilaksanakan pada tanggal 17, 19, dan 22 Maret 2016 pada pukul 15.00 sampai pukul $17.00 \mathrm{di}$ lapangan bolabasket SMA Negeri 1 Kauman Kabupaten Tulungagung dengan subjek 30 peserta ekstrakurikuler, dan diperoleh hasil yaitu dari aspek kejelasan diperoleh persentase $88 \%$ dengan kategori sangat valid, aspek kemenarikan diperoleh persentase $89,1 \%$ dengan kategori sangat valid, dari aspek kemudahan diperoleh persentase $89,6 \%$ dengan kategori sangat valid dan aspek kemanfaatan diperoleh persentase $90,7 \%$ dengan kategori sangat valid. Dari keempat aspek tersebut diperoleh rata-rata keseluruhan yaitu dengan persentase $89,3 \%$ dengan kategori sangat valid.

Adapun saran-saran dari uji coba kelompok besar terhadap hasil pengembangan model latihan jump shoot untuk peserta ekstrakurikuler bolabasket SMA Negeri 1 Kauman Kabupaten Tulungagung yaitu perlu adanya keterangan rebound pada model latihan agar model-model latihan yang dikembangkan lebih mudah dipahami. Dari hasil uji coba kelompok besar tersebut dapat disimpulkan bahwa produk pengembangan model latihan jump shoot untuk peserta ekstrakurikuler bolabasket SMA Negeri 1 Kauman Kabupaten Tulungagung dapat dipergunakan.

\section{PEMBAHASAN}

Hasil akhir dari kegiatan penelitian pengembangan ini adalah berupa produk pengembangan model latihan jump shoot untuk peserta ekstrakurikuler bolabasket SMA Negeri 1 Kauman Kabupaten Tulungagung yang dikemas dalam bentuk buku saku.

Menurut Winarno (2011:57) dalam pendidikan jasmani, rancangan penelitian pengembangan dapat digunakan sebagai upaya pencegahan masalah pendidikan dan pembelajaran. Jadi kegiatan penelitian dan pengembangan ini dilakukan agar dapat menjadi salah satu alternatif untuk mengati masalah yang ada pada ekstrakurikuler bolabasket SMA Negeri 1 Kauman Kabupaten Tulungagung.

Ketika melakukan kegiatan penelitian dan pengembangan juga tidak harus menciptakan sebuah produk akan tetapi dapat mengembangakn sebuah produk yang ada. Menurut pendapat Sukmadinata (2005:164) menyatakan bahwa "Pengembangan adalah mengembangkan suatu produk atau menyempurnakan produk yang 
Muhammad Faishol Harun, Pengembangan Model Latihan Jump Shoot Untuk Peserta Ekstrakurikuler Bolabasket SMA Negeri 1 Kauman Kabupaten Tulungagung

telah ada dan produk tersebut dapat dipertanggungjawabkan.

Produk pengembangan model latihan jump shoot untuk ekstrakurikuler bolabasket SMA Negeri 1 Kauman Kabupaten Tulungagung ini memiliki kelebihan-kelebihan sebagai salah satu alternatif pada saat latihan yang dapat dimanfaatkan untuk meningkatkan penguasaan teknik jump shoot dengan baik dan benar. Produk pengembangan model latihan jump shoot ini dikemas dalam bentuk buku saku yang berisikan tentang kajian teori tentang sejarah permainan bolabasket, pengertian permainan bolabasket, macam-macam teknik dasar permainan bolabasket, pengertian shooting dalam permainan bolabasket, pengertian jump shoot dalam permainan bolabasket dan model-model latihan jump shoot dalam permainan bolabasket. Produk pengembangan model latihan jump shoot ini mempunyai kelebihan antara lain: (1) peserta ekstrakurikuler dapat mempraktikkan berbagai model- model latihan jump shoot. (2) pada buku saku terdapat gambar dari model-model latihan untuk mempermudah peserta ekstrakurikuler mempelajarinya. (3) terdapat keterangan gambar dan tata cara pelaksanaan dari setiap model-model latihan yang dikembangkan sehingga peserta ekstrakurikuler dapat mudah memahami dan mengerti. (4) buku saku juga lebih praktis untuk dibawa kemana saja dan dapat mempelajarinya kapan saja. (5) gambar model-model latihan yang ada dalam buku saku dibuat berwarna agar peserta ekstrakurikuler lebih tertarik untuk mempelajarinya. Hasil produk pengembangan model latihan jump shoot untuk peserta ekstrakurikuler bolabasket SMA Negeri 1 Kauman Kabupaten Tulungagung diperoleh berdasarkan hasil analisis kebutuhan dengan menggunakan kuesioner yang diberikan kepada pelatih dan peserta ekstrakurikuler.

Produk pengembangan model latihan jump shoot untuk peserta ekstrakurikuler bolabasket SMA Negeri 1 Kauman Kabupaten Tulungagung ini berdasarkan hasil analisis kebutuhan dengan menggunakan kuesioner yang diberikan kepada pelatih dan peserta ekstrakurikuler. Dalam proses pengumpulan data dalam pendidikan jasmani menurut Winarno (2013:104) yaitu tes dan non tes, instrumen tes berupa: (1) tes ketrampilan, (2) testulis, dan (3) tes lisan. Sedangkan nontes berupa: (1) angket kuesioner, (2) wawancara, (3) observasi, (4) inventori dan, (5) dokumentasi. Pada penelitian ini peneliti menggunakan teknik observasi dan penyebaran angket untuk mengumpulkan informasi. Jadi pada penelitian ini menggunakan teknik observasi dan penyebaran kuesioner. Teknik observasi digunakan peneliti untuk memperoleh informasi keadaan sebenarnya yang ada pada kegiatan ekstrakurikuler.

Ketika proses observasi peneliti melihat dan mengamati bagaimana kegiatan latihan di ekstrakurikuler bolabasket SMA Negeri 1 Kauman Kabupaten Tulungagung dan mencatat segala sesuatu yang terjadi pada saat latihan berlangsung. Apabila ada suatu kejanggalan yang terjadi saat kegiatan latihan berlangsung dan biasanya kejanggalan tersebut yang menjadi masalah yang menghambat kegiatan latihan. Kemudian setelah mencatat masalh-masalah yang ada, peneliti kemudian membagikan kuesioner kepada pelatih maupun peserta ekstrakurikuler, kuesioner ini diberikan untuk memperoleh informasi dan menegatahui seberapa benar dan seberapa luas masalah yang menghambat dalam proses kegiatan latihan.

Hasil dari penyebaran kuesioner kepada pelatih dan peserta ekstarkurikuler bolabasket SMA Negeri 1 Kauman Kabupaten Tulungagung yaitu: Pelatih mengatakan bahwa teknik shooting yang tingkat keberhasilannya paling kurang adalah jump shoot, peserta kurang menguasai teknik jump shoot, peserta juga sangat sering mengalami kesulitan dalam melakukan teknik jump shoot, pelatih juga jarang memberikan model latihan jump shoot, pelatih setuju jika peneliti mengembangkan model latihan jump shoot, pelatih juga setuju jika pengembangan model latihan jump shoot dikemas dalam bentuk buku saku. Kemudian hasil angket dari peserta ekstrakurikuler bolabasket SMA Negeri 1 Kauman Kabupaten Tulungagung yaitu (1) sebanyak 32 peserta (84\%) menyatakan jump shoot merupakan teknik shooting yang paling sulit dilakukan, (2) sebanyak 38 peserta (100\%) menyatakan pelatih jarang memberikan model latihan jump shoot, (3) sebanyak 38 peserta (100\%) menyatakan model latihan jump shoot yang diberikan pelatih tidak menarik, (4) sebanyak 38 
peserta (100\%) menyatakan setuju jika peneliti mengembangkan model latihan jump shoot, (5) sebanyak 34 peserta (89\%) memilih untuk pengembangan model latihan jump shoot dikemas dalam bentuk buku saku.

Setelah peneliti mengetahu masalah yang mengahmabt kegiatan latihan di ekstrakurikulr bolabasket SMA Negeri 1 Kauman Kabupten Tulungagung kemudian peneliti merancang produk awal dengan mengembangkan model latihan jump shoot yang dikemas dalam bentuk buku saku yang berisikan tentang kajian teori tentang sejarah permainan bolabasket, pengertian permainan bolabasket, macam-macam teknik dasar permainan bolabasket, pengertian shooting dalam permainan bolabasket, pengertian jump shoot dalam permainan bolabasket dan model-model latihan jump shoot dalam permainan bolabasket. Model latihan pada rancangan produk awal terdiri dari 10 model latihan antara lain: (a) Model latihan I (two dribble jump shoot), (b) Model latihan II (jump shoot right free throw area), (c) Model latihan III (passing, run and jump shoot), (d) Model latihan IV (jump shoot free throw area), (e) Model latihan V (three dribble jump shoot),(f) Model latihan VI (run zig-zag jump shoot) (g) Model latihan VII (dribble zig-zag jump shoot), (h) Model latihan VIII (dribble, passing and jump shoot), (i) Model latihan IX (zig-zag dribble, passing, run and jump shoot), (j) Model latihan $\mathrm{X}$ (jump shoot five position).

Menurut Bompa (1994) (dalam Budiwanto, 2011:12) menyatakan pendapatnya bahwa latihan merupakan suatu kegiatan olahraga yang sistematis dalam waktu yang panjang, ditingkatkan secara bertahap dan perorangan, bertujuan untuk membentuk manusia yang berfungsi fisiologis dan psikologisnya untuk memenuhi tuntutan tugas. Menurut Harsono (1988: 100) "Tujuan serta sasaran utama dari latihan atau trainning adalah untuk membantu atlet meningkatkan keterampilan dan prestasinya semaksimal mungkin". Jadi model latihan yang dikembangkan ini bertujuan untuk meningkatkan keterampilan dan membentuk peserta ekstrakurikuler pada fisiologis da psikologisnya.

Menurut Budiwanto (2012:22) berpendapat bahwa "Dalam mengatasi kebosanan dan latihan yang monoton, diharapkan seorang pelatih kreatif dengan memiliki banyak pengetahuan dan berbagai jenis latihan yang memungkinkan dapat bervariasi dan berganti-ganti secara periodik". Jadi model-model yang dikembangka peneliti harus bervariasi sehingga peserta ekstrakurikuler bolabasket tidak mengalami kebosanan dan kejenuhan pada saat melakukan latihan.

Tahapan selanjutnya setelah merancang produk awal yaitu melakukan evaluasi ahli yaitu: 1 ahli permainan bolabasket, 1 ahli kepelatihan permainan bolabasket, 1 ahli media. Evaluasi kepada para ahli dilakukan untuk mengetahui apakah produk yang dibuat bisa digunakan dan untuk mengetahuii saran-saran untuk perbaikan produk yang dibuat dan pengumpulan data dengan cara dengan menyebarkan kuesioner kepada para ahli tersebut.

Kuesioner yang telah diberikan kepada evaluasi ahli permainan bolabasket Oni Bagus Januarto, M. Kes. selaku Dosen jurusan Pendidikan Jasmani dan Kesehatan Fakultas IImu Keolahragaan Universitas Negeri Malang mengenai produk yang berupa pengembangan model latihan jump shoot ini memiliki tujuan untuk mengetahui informasi dan pendapatnya menegani produk pengembangan model latihan jump shoot ini. Secara kesuluruhan analisis data menunjukan angka presentase $78 \%$ kategori cukup baik. Kuesioner yang telah diberikan kepada ahli kepelatihan permainan bolabasket Ardhiansyah Rachmanu mengenai produk pengembangan model latihan jump shoot secara kesuluruhan analisis data menunjukan angka presentase $78 \%$ kategori cukup baik.

Dari evaluasi ahli permainan bolabasket dan ahli kepelatihan permainan bolabasket disimpulkan bahwa bahwa produk yang telah dikembangkan peneliti jelas, menarik, bermanfaat, dan dapat dilanjutkan pada uji kelompok kecil dan besar. Produk pengembangan model latihan jump shoot yang peneliti kembangkan ini jelas karena gambar dari model-model latihan jump shoot yang dikembangkan sudah jelas dan peserta ekstrakurikuler dapat mudah untuk memahaminya. Produk pengembangan model latihan jump shoot yang peneliti kembangkan ini menarik karena model-model latihan 
Muhammad Faishol Harun, Pengembangan Model Latihan Jump Shoot Untuk Peserta Ekstrakurikuler Bolabasket SMA Negeri 1 Kauman Kabupaten Tulungagung

jump shoot yang peneliti kembangkan dilakukan dengan adanya kombinasi dari passing, dribble, dan lari. Gambar yang terdapat pada buku saku juga dibuat berwarna sehingga peserta ekstrakurikuler dapat tertarik untuk membacanya. Produk pengembangan model latihan jump shoot yang peneliti kembangkan ini bermanfaat karena model latihan yang dikembangkan ini sangat bermanfaat digunakan saat latihan jump shooti permainan bolabasket.

Peneliti kemudian membagikan kuesioner kepada ahli media yaitu Eka Pramono Adi, S. I. P. M, Si. mengenai produk berupa pengembangan model latihan jump shoot ini secara keseluruhan analisis data menunjukan angka presentase $77,7 \%$. Jadi dapat disimpulkan bahwa produk yang dikembangkan peneliti yang berupa model latihan jump shoot jelas, menarik, sesuai dan dapat dipahami. Produk pengembangan model latihan jump shoot ini sudah jelas karena gamba cover, tulisan dan gambar modelmodel latihan jump shoot yang dikembangkan ini mudah untuk dipahami. Produk pengembangan model latihan jump shoot ini menarik karena cover dan gambar modelmodel latihan yang ada pada buku saku dibuat berwarna sehingga peserta ekstrakurikuler tertarik untuk mempelajari. Produk pengembangan model latihan jump shoot sesuai karena isi dari buku saku sudah sesuai dengan kriteria bahan ajar yang akan diberikan dan dipelajari oleh peserta ekstrakurikuler bolabasket SMA Negeri 1 Kauman Kabupaten Tulungagung. Setelah melakukan evaluasi ahli produk pengembangan model latihan jump shoot yang telah dikembangkan dapat dilanjutkan ke tahap uji coba kelompok kecil.

Uji coba kelompok kecil menggunakan subjek 8 peserta ekstrakurikuler bolabasket SMA Negeri 1 Kauman Kabupaten Tulungagung dengan membagikan kuisoner dan secara keseluruhan analissi data tersebut menunjukan angka yaitu $83,2 \%$ dengan kategori cukup valid. Dan dapat disimpulkan bahwa pengembangan produk pengembangan model latihan jump shoot untuk peserta ekstrakurikuler bolabasket SMA Negeri 1 Kauman Kabupaten Tulungagung diterima oleh peserta ekstrakurikuler dan dapat dilanjutkan ke tahap uji kelompok besar dengan beberapa revisi yang diperoleh dar saran-saran dari uji coba kelompok kecil. Setelah melakukan uji coba kelompok kecil kemudian melakukan revisi produk, revisi produk ini dilakukan untuk menyempurnakan produk yang dikembangkan sesuai dengan saran-saran uji coba kelompok kecil.

Uji coba kelompok besar dengan menggunakan subjek 30 peserta peserta ekstrakurikuler bolabasket SMA Negeri 1 Kauman Kabupaten Tulungagung dengan membagikan kuisoner dan diperoleh hasil analisis data secara keseluruhan menunjukkan persentase sebesar $89,3 \%$ dengan kategori sangat valid. Dari hasil uji coba kelompok besar tersebut dapat disimpulkan bahwa pengembangan model latihan jump shoot untuk peserta ekstrakurikuler bolabasket SMA Negeri 1 Kauman Kabupaten Tulungagung dapat dipergunakan dan diterima oleh peserta ekstrakurikuler bolabasket SMA Negeri 1 Kauman Kabupaten Tulungagung.

Setelah melakukan uji coba kelompok besar kemudian melakukan revisi produk akhir yang diperoleh dari saran-saran dari uji coba kelompok besar. Dan hasil akhir dari produk yang dikembangkan oleh peneliti ini berupa pengembangan model latihan jump shoot untuk peserta ekstrakurikuler bolabasket SMA Negeri 1 Kauman Kabupaten Tulungagung yang dikemas dalam bentuk buku saku. Adapun produk akhir model latihan jump shoot ini terdiri dari 9 model latihan antara lain: (a) Model latihan II (jump shoot right free throw area), (b) Model latihan III (passing, run and jump shoot), (c) Model latihan IV (jump shoot free throw area), (d) Model latihan V (three dribble jump shoot),(e) Model latihan VI (run zig-zag jump shoot) (f) Model latihan VII (dribble zigzag jump shoot), (g) Model latihan VIII (dribble, passing and jump shoot), (h) Model latihan IX (zig-zag dribble, passing, run and jump shoot), (i) Model latihan X (jump shoot five position).

\section{KESIMPULAN}

Berdasarkan hasil penelitian dan pengembangan ini terhadap pengembangan model latihan jump shoot untuk peserta ekstrakurikuler bolabasket SMA Negeri 1 Kauman Kabupaten Tulungagung yang telah dilakukan melalui beberapa tahap dapat disimpulkan bahwa pengembangan model 
latihan jump shoot untuk peserta ekstrakurikuler bolabasket SMA Negeri 1 Kauman Kabupaten Tulungagung sangat valid, sangat menarik, sangat jelas, sangat sesuai, dan sangat bermanfaat serta dapat digunakan pada latihan jump shoot pada ekstrakurikuler bolabasket SMA Negeri 1 Kauman Kabupaten Tulungagung.

\section{SARAN}

Saran pemanfaatan yaitu produk pengembangan model lathan jump shoot ini diharapkan dapat meningakatkan semangat dan antuasis dalam latihan serta juga dapat dijadikan sumber belajar dan pedoman saat latihan di ekstrakurikuler serta saat latihan di luar jam kegiatan ekstrakurikuler bolabasket SMA Negeri 1 Kauman Kabupaten Tulungagung. Produk yang dihasilkan merupakan produk yang ditujukan untuk ekstrakurikuler bolabasket SMA Negeri 1 Kauman Kabupaten Tulungagung.

Saran diseminasi yaitu penyebarluasan dari produk yang telah dikembangkan ke sasaran yang lebih luas, peneliti memberikan saran sebagai berikut: (a) sebelum produk ini disebarluaskan ke sasaran lebih luas sebaiknya produk ini dievaluasi dan disesuaikan dengan kondisi sasaran yang ingin dituju. (b) sebelum disebarluaskan sebaiknya produk yang telah dikembangkan ini disosialisasikan kepada pihak-pihak terkait dengan cabang permainan bolabasket.

Saran pengembangan produk lebih lanjut yaitu dalam pengembangan yang lebih lanjut, peneliti memberikan saran sebagai berikut: (a) model latihan jump shoot yang dikembangkan ini diharapkan dikembangkan lagi supaya lebih variatif sehingga dapa mencapai tujuan yang diharapkan. (b) subjek penelitian diharapkan lebih luas, tidak hanya di ekstrakurikuler bolabasket SMA Negeri 1 Kauman Kabupaten Tulungagung, akan tetapi disekolah-sekolah lainnya. (c) sebaiknya dilakukan penelitian lebih lanjut untuk mengetahui tingkat efektivitas produk yang dikembangkan ini, karena hasil pengembangan ini masih terbatas sampai tersusunnya sebuah produk saja.

\section{DAFTAR RUJUKAN}

Ahmadi, N. 2007. Permainan Bolabasket. Solo: Era Intermedia.

Ardhana. 2002. Konsep Penelitian Pengembangan dalam Bidang Pendidikan dan Pembelajaran. Malang: Universitas Negeri Malang.

Budiwanto, S. 2011. Metodologi Kepelatihan Olahraga. Malang: FIK UM.

Budiwanto, Setyo. 2012. Metodologi Latihan Dan Olahraga. Malang: Jurusan IImu Keolahragaan FIP UM Universitas Negeri Malang.

Borg, W. R. \& Gall, M. D. 1983. Education Reseach An Introduction. New York: Longman.

Harsono. 1998. Coaching dan Aspek-Aspek Psikologis Dalam Coaching. Jakarta: Departemen Pendidikan dan Kebudayaan.

Jerrytama, B. 2015. Pengembangan Model Latihan Teknik Jump Shoot Untuk Peserta Ekstrakurikuler Bolabasket Putra Di SMP Negeri 1 Trenggalek Melalui Video Pembelajaran Instruksional. Skripsi tidak diterbitkan: Universitas Negeri Malang.

Liberman. 1991. Panduan Lengkap Bolabasket untuk Wanita. Jakarta: Raja Grafindo Persada.

Lutan, R. 1986. Pengelolaan Interaksi Belajar Mengajar Intrakurikuler, Kokurikuler, dan Ekstrakurikuler. Jakarta: Karunika Jakarta Universitas Terbuka.

Muhajir. 2007. Pendidikan Jasmani, Olahraga dan Kesehatan. Jakarta: Erlangga.

Mukhadis, A. 2013. Evaluasi Program Pembelajaran Bidang Teknologi. Malang: Bayumedia Publishing

Okazaki, A. \& Rodacki, A. 2012. Increased Distance Of Shooting On Basketball Jump 
Muhammad Faishol Harun, Pengembangan Model Latihan Jump Shoot Untuk Peserta Ekstrakurikuler Bolabasket

Shot.1(1).(http://hera.ugr.es/doi/1501 986X.pdf) diakses pada 19 Mei 2016

Pandey. dkk. 2012. The Relationship Of The Selected Kinematic Variables With The Performance Of Low Dribble In Basketball At Execution Phase. 5(2).(Online).(http://www.indjst.org/in dex.php/indjst/article/viewFile/30351/ 26282) diakses pada 18 Januari 2016

Pauweni, M. 2012. Pengembangan Model Permainan Bolabasket Taki Sebagai Media Pembelajaran Pendidikan Jasmani, Olahraga dan Kesehatan Siswa Sekolah Dasar Kelas Atas Di Kota Gorontalo. 1(1) (Online). (http:// journal.unnes.ac.ld/sju/index.Php/jpe s/article/download /99/90) diakses tanggal 26 Nopember 2015.

Poomsalood \& Pakulanon. 2015. Effects of 4-week Plyometric Training on Speed, Agility, and Leg Muscle Power in Male University Basketball Players: A Pilot Study. 36(1). (Online). (http://kasetsartjournal.ku.ac.th/kuj_fil es /2016/A160107153059 9976.pdf) diakses pada 18 Januari 2016.

Rosdiani, D. 2012. Model Pembelajaran Langsung dalam Pendidikan Jasmani dan Kesehatan. Bandung: Alfabeta.

Rohmawan, I. A. A. 2014. Pengembangan Buku Ajar Pendidikan Jasmani Untuk Siswa Kelas Xi Semester 1 SMA.1(1).(Online).(http://kemenpora. go.id/ebook/ Jurnal Odlk Kemenpora_vol_1_Mei_2014.pdf) diakses pada 15 Desember 2015

Saichudin \& Januarto. 1991. Teknis Dasar dan Peraturan Permainan Bolabasket. Institut Keguruan dan IImu Pendidikan Malang:Departemen Pendidikan dan Kebudayaan.

Sukmadinata. 2005. Metode Penelitian Pendidikan. Bandung: PT Remaja Rosdakarya.

Wendri. dkk. 2012. Sumbangan Kekuatan Otot Jari, Otot Perut dan Daya Ledak Otot Tungkai dalam Reverse Lay Up.
1(2). (Online). (http://journal.unnes. ac.id/ sju/index.php/jssf) diakses tanggal 2 Desember 2015.

Winarno. 2011. Metodologi Penelitian dalam Pendidikan Jasmani. Malang: Cakra Utama Press.

Winarno. 2013. Metodologi Penelitian dalam Pendidikan Jasmani. Malang: Fakultas IImu Keolahragaan Negeri Malang.

Yanto, T. 2013. Pengembangan VCD Latihan Jump Shoot Untuk Peserta Ekstrakurikuler Bolabasket Putra Di SMP Negeri 1 Wlingi Kabupaten Blitar. Skripsi tidak diterbitkan: Universitas Negeri Malang 